\title{
Krónikus gerincfájdalommal élő személyek életminőségét befolyásoló kognitív tényezök
}

\section{Cognitive factors influencing the quality of life of people with chronic back pain}

\begin{tabular}{ll}
\hline Szerző: & Békefi Evelin; Teleki Szidalisz Ágnes \\
Kulcsszavak: & $\begin{array}{l}\text { krónikus gerincfájdalom; mindfulness; fájdalom-katasztrofizáció; félelem-elkerülési } \\
\text { hiedelmek; életminőség } \\
\text { chronic back pain; mindfulness; pain catastrophizing; fear-avoidance beliefs; quality } \\
\text { of life }\end{array}$ \\
\hline
\end{tabular}

Beküldve: 2021. 05. 18., doi: $10.24365 /$ ef.v62i3.6106

\begin{abstract}
Összefoglaló
Bevezetés: A krónikus gerincfájdalom a második leggyakrabban előforduló betegség a krónikus betegségek listáján. Az állapottal való együttélés során a biológiai tényezők mellett kiemelt szerepet kapnak a pszichológiai tényezők is, amik alakíthatják a betegséghez való alkalmazkodás sikerességét. Vizsgálatunkban krónikus gerincfájdalommal élő személyek körében vizsgáltuk a mindfulness, a fájdalomkatasztrofizáció és a félelemelkerülési hiedelmek egészségi állapottal kapcsolatos életminőségre gyakorolt hatását.
\end{abstract}

Módszertan: Keresztmetszeti, kvantitatív kutatásunkban krónikus gerincfájdalommal élő személyek vettek részt, akik a közösségi médiában található specifikus csoportokból kerültek ki $(n=65$; férfi $=10$; nő $=55$; életkorátlag $=49,2$ ). A kutatásunkban a Mindful Attention Awareness Scale -MAAS, Pain Catastrophizing Scale - PCS, Fear and Avoidance Belief Questionnaire - FABQ-H és a Short Form Health Survey - SF-36 standardizált kérdőíveket alkalmaztuk. Hipotéziseink vizsgálata kapcsán Pearson korrelációanalízist és többszörös lineáris regresszióelemzést végeztünk.

Eredmények: A megkérdezettek körében a mindfulness, a fájdalom-katasztrofizáció és a félelemelkerülési hiedelmek között szignifikáns kapcsolatot találtunk. Az alacsonyabb fokú mindfulness magasabb fájdalom-katasztrofizációval és félelemelkerülési hiedelmekkel járt együtt, viszont pozitív kapcsolatot mutatott az életminőséggel. Az adatokat tovább vizsgálva azt az eredményt kaptuk, hogy az egészségi állapottal kapcsolatos rosszabb életminőséget a mindfulness kisebb mértéke, a magasabb fokú fájdalom-katasztrofizáció és félelemelkerülési hiedelmek jósolják be legerőteljesebben.

Következtetések: Eredményeink alapján elmondható, hogy a krónikus gerincfájdalommal élők egészségi állapottal kapcsolatos életminőségét az alacsonyabb fokú mindfulness, a magasabb fokú fájdalom-katasztrofizáció és félelemelkerülési hiedelmek negatívan befolyásolják. Eredményeink azonban aláhúzzák ezen pszichológiai tényezőknek a betegek életében betöltött szerepét, aminek kapcsán egy olyan multidiszciplináris kezelés fontosságát hangsúlyozzuk, amelyben a fizikai tünetek mellett a pszichológiai tényezők is kiemelt szerepet kapnak a magasabb hatásfokú egészségkimenet elérése érdekében.

\section{Summary}

Introduction: Chronic back pain is the second most common disease on the list of chronic diseases today. In addition to biological factors, psychological factors that can shape the course of the disease play a key role in coping with the condition. In our study, we examined the impact of mindfulness, pain catastrophizing and fear and avoidance beliefs in relation to health-related quality of life between people with chronic back pain.

Methodology: Our cross-sectional, quantitative research included individuals with chronic back pain who came from specific groups on social media $(n=65$; $m e n=10$; women $=55$; agemean $=49,2)$. In the 
study, the Mindful Attention Awareness Scale - MAAS, Pain Catastrophizing Scale - PCS, Fear and Avoidance Belief Questionnaire - FABQ- $\mathrm{H}$, and the Short Form Health Survey - SF-36 were used. To test our hypothesis Pearson correlation and multiple linear regression analysis were applied.

Results: In our sample, we have found a significant association between mindfulness, pain catastrophizing, and fear-avoidance beliefs. Lower levels of mindfulness was associated with higher pain catastrophizing and fear-avoidance beliefs, but showed a positive correlation with quality of life. Further examining the data, we found that the lower levels of health-related quality of life was predicted by lower levels of mindfulness and higher levels of pain catastrophizing and fear-avoidance beliefs.

Conclusions: According to our results, the health-related quality of life of people with chronic back pain is negatively affected by lower levels of mindfulness and higher levels of pain catastrophizing and fear-avoidance beliefs. Our results underscore the role of these psychological factors in patients 'lives, emphasizing the importance of a multidisciplinary treatment in which, in addition to physical symptoms, psychological factors also play a key role in achieving higher health outcomes.

\section{BEVEZETÉS}

\section{Krónikus fájdalom}

A krónikus fájdalom mára már olyan gyakorivá vált, hogy a becslések szerint az emberek $20 \%$-át érinti világszerte és az orvoslátogatások 1520\%-át teszi ki (Treede et al., 2019). A krónikus fájdalom kifejezés olyan fájdalomra utal, amely folyamatosan fennáll, vagy idővel súlyosbodik. Szemben az akut fájdalommal, amely hirtelen jelentkezik egy adott sérülés hatására, és általában kezelhető, a krónikus fájdalom hosszabb időn át fennmarad, és gyakran ellenáll az orvosi kezelésnek. A Nemzetközi Fájdalomkutató Társaság (International Association for the Study of Pain, IASP) definíciója szerint akkor tekintjük a fájdalmat krónikusnak, ha három hónapnál tovább tart, vagy a normál szöveti gyógyulási időn túl is jelen van (Merskey, 2002). Ezt a meghatározást széles körben alkalmazták a kutatásokban és a klinikai gyakorlatban, de ezzel együtt túl szűknek is bizonyult, mivel nem tartalmaz funkcionális és pszichobiológiai tényezőket, amelyek nélkülözhetetlenek a pontos értékeléshez (Flor \& Turk, 2011). Éppen ezért ma már úgy tartják, hogy a hosszantartó fájdalomnak való kitettség, a stresszre adott válasz, a kogníciók és az érzelmek mind módosithatják az észlelt fájdalom egyéni tapasztalatait (Apkarian, Baliki \& Geha, 2009). A jelenlegi ismeretek alapján a biopszichoszociális modell tünik a legjobb meg-közelítésnek a krónikus fájdalom tanulmányozásában és megértésében (Gatchel, Peng, Peters, Fuchs \& Turk., 2007). Ellentétben az egydimenziós biomedikális perspektívával, amely a krónikus fájdalom etiológiai és patofiziológiai magya- rázatára összpontosít, vagy a pszichogén nézettel, amely a fájdalmat valamilyen belső konfliktus fizikai megnyilvánulásának tekinti, a biopszichoszociális modell integrált mintát/képet nyújt, amely magában foglalja a tisztán mechanikai és fiziológiai folyamatokat, valamint a pszichológiai és társadalmi kontextusbeli változókat is, amelyek a krónikus fájdalmat okozhatják. Amíg a biomedikális modell a betegség lefolyására helyezi a hangsúlyt, addig a biopszichoszociális modell a betegség biológiai, pszichológiai és szociokulturális változói közötti dinamikus, odavissza ható kölcsönhatásokat veszi figyelembe, amelyek az emberek fájdalomra adott reakcióit formálják (Turk \& Flor, 1999).

A krónikus fájdalom mögött számos okot felsorakoztathatunk, például a fájdalomérző receptorok (nociceptorok) tartós stimulációja, a perifériás vagy centrális idegrendszer károsodása (pl.: porckorongsérv okozta idegi irritáció) vagy ezek kombinációja (pl.: diabéteszes neuropátia). Az imént felsoroltak viszonylag jól meghatározható eredetű fájdalmak, de gyakran előfordulnak generalizált, krónikus fájdalomszindrómák, ahol a betegség oka nem határozható meg egyértelműen (pl.: fibromialgia vagy kimutatható patológiai elváltozás nélkül fennálló hát- vagy deréktáji fájdalom) (Szántó, 2012).

\section{Krónikus gerincfájdalom}

A Központi Statisztikai Hivatal $(\mathrm{KSH} ; 2020)$ adatai szerint a derék- vagy hátgerincprobléma a magasvérnyomás-betegség után a második leggyakrabban előforduló krónikus betegség a magyarországi lakosság körében, de a nyaki fájda- 
lom vagy egyéb krónikus nyaki gerincprobléma is szerepel a tíz leggyakoribb krónikus betegség között (KSH, 2020). Azt, hogy a krónikus hátfájás az átlagpopulációban is kifejezetten gyakori, egy nagy elemszámú, francia felmérés is alátámasztja, ahol majd' húszezer felnőtt 38\%-áról derült ki, hogy krónikus derékfájdalomban szenved. Ez a kutatás azt is kihangsúlyozta, hogy a krónikus derékfájdalom jelentősen alacsonyabb életminőséget is eredményez az egészséges résztvevőkhöz képest (Husky, Ferdous Farin, Compagnone, Fermanian \& Kovess-Masfety, 2018).

\section{A krónikus fájdalomhoz társuló pszichológiai tényezők}

Napjainkban már nincs is kétség afelől, hogy a fájdalom egy komplex észlelési tapasztalat, amelyet pszichoszociális tényezők széles skálája befolyásol, ideértve az érzelmeket, a társadalmi és környezeti interakciókat, a szociokulturális hátteret, a fájdalom egyéni jelentését, a biológiai hátteret, valamint a hiedelmeket, attitűdöket és elvárásokat. A hónapokig és akár évekig elhúzódó fájdalom az emberi múködés minden aspektusára hatással lesz egy idő után: az érzelmekre, interperszonális kapcsolatokra, munkavégzésre és fizikai tapasztalatokra.

\section{Félelem és elkerülési hiedelmek}

A vizsgálatunk szempontjából releváns tényezők magyarázatára és komplex elemzésére jól alkalmazható elméleti keretet nyújthat a Félelemelkerülés kognitív viselkedéses modellje, vagy ahogy ma ismerjük: Krónikus fájdalom félelemelkerülési modellje (Vlaeyen et al., 1995), amit az 1. ábra szemléltet. A modell azt mondja $\mathrm{ki}$, hogy ha valaki a fájdalom élményét jelentősen fenyegetőnek címkézi és katasztrofizáló gondolatai támadnak, akkor kialakul a fájdalommal kapcsolatos félelem (Crombez, Eccleston, Van Damme, Vlaeyen \& Karoly, 2012). A már biopszichoszociális keretben létrejött Félelemelkerülés-modell azt a folyamatot írja le, amely során a fájdalmat átélő személyek olyan ördögi körforgásba kerülhetnek, ami krónikus dizabilitást és szenvedést idézhet elő. A fájdalomhoz köthető félelemelkerülés és a krónikus fájdalom közti kapcsolat már több mint három évtizede vizsgált koncepció, főleg mozgásszervi fájdalom és dizabilitás függvényében (Lundberg, Grimby-Ekman, Verbunt $\&$ Simmonds, 2011).

\section{1. ábra: A Krónikus fájdalom félelemelkerülési modellje}

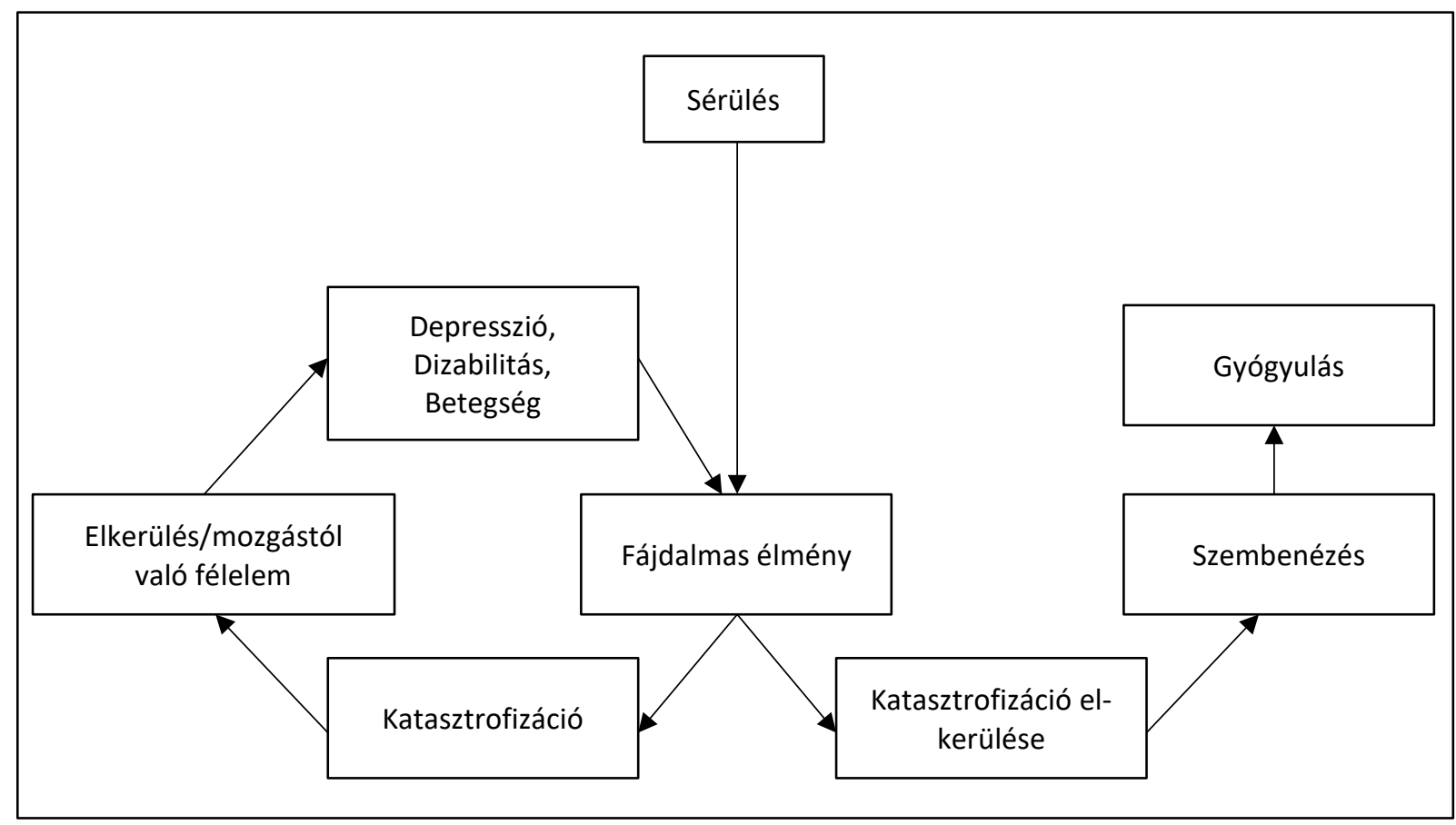

Forrás: Vlaeyen et al. (1995) nyomán 
A katasztrofizáló gondolatok megannyi negatív következményt hordoznak magukban, elsősorban a fizikai aktivitás csökkenése miatt: erősödő betegszerep, családi kapcsolatokban bekövetkező romlás, csökkenő fizikai terhelhetőség és szellemi frissesség. Továbbá, a gyakori gyógyszerszedés miatt függőség alakulhat ki, és az egészségügyi szolgáltatások igénybevétele is fokozódhat (Kori, Miller \& Todd, 1990., idézi Simoncsics \& Stauder, 2017).

A modell elemei közül vizsgálatunkba emeltük a fájdalom-katasztrofizációt, a félelemelkerüléshiedelmek tényezőit, valamint a modellben eredetileg nem szereplő, ám véleményünk szerint protektív hatásúként kezelhető mindfulness konstruktumát, míg kimeneti változóként az egészséggel kapcsolatos életminőséget jelöltük meg.

\section{Fájdalom-katasztrofizáció}

A fájdalom-katasztrofizáció a fájdalmas inger fenyegető mivoltának felnagyítására és a fájdalom miatti tehetetlenség érzésére való hajlamra, valamint a fájdalommal kapcsolatos gondolatok gátlásának képtelenségére utal, főleg egy fájdalmat okozó esemény elővételezése során, közben vagy azt követően (Quartana, Campbell \& Edwards, 2010). A katasztrofizáció negatívérzelem-fókuszú megküzdési stratégia, amelyet a fájdalom kontextusában túlzottan negatív fájdalom-orientációként lehet felfogni, ami félelmet, diszkomfortérzést, aggodalmat és tehetetlenséget vált ki. Három fő dimenziója a rumináció, felnagyítás és tehetetlenség (Sullivan et al., 2001).

\section{Mindfulness}

A buddhizmus gyökereihez visszanyúló mindfulness, azaz tudatos jelenlét az 1970-es években terjedt el a nyugati kultúrában Dr. Jon KabatZinn áttörő munkájának köszönhetően a mindfulness-alapú stresszcsökkentés elnevezésű program megalapításával (Kabat-Zinn, 1982). A tudatos jelenlétet úgy határozták meg, mint a jelen pillanat megélésére való figyelem fókuszálása, és annak ítélkezés nélküli elfogadása anélkül, hogy közben egyéb gondolatok vagy érzelmek terelnék el a figyelmet (Bishop et al., 2004). A mindfulness-alapú intervencióknak pont az a célja, hogy a résztvevőket megtanítsák arra, hogy a jelen pillanatban történő ingerekre figyeljenek. Mindezt olyan gyakorlatok révén teszik, amelyek javítják a testi érzések tudatosítását, valamint a gondolatok és érzések ítélkezés nélküli megfigyelését (Sipe \& Eisendrath, 2012).

Ismereteink szerint egyetlen kutatás kísérelte meg a modellbe emelni a mindfulness konstruktumát, amely megerősítette, hogy a jelentudatosság csökkenti a krónikus fájdalmat azáltal, hogy befolyásolja a Krónikus fájdalom félelemelkerülési modelljében szereplő tényezőket. A kutatásba 104 ausztrál, krónikus fájdalommal élő beteget vontak be, és azt is alátámasztották, hogy a mindfulness mérsékli a fájdalom intenzitása és a katasztrofizálás közötti kapcsolatot. Mindez arra utal, hogy az, hogy egy személy a fájdalma miatt rágódni, örlődni kezd-e, bizonyos mértékben attól függ, hogy képes-e a pillanatnyi élményeire, tapasztalataira koncentrálni. Ezek az eredmények azért is hangsúlyosak, mert úgy tűnik, a tudatos jelenlét fontos szerepet játszhat a krónikus fájdalom szúrésében és a korai beavatkozásban. Lévén, hogy a Félelemelkerülés kognitív viselkedéses modelljében már korán megjelenik, valószínúsíthető, hogy az alacsony szintű mindfulness a betegek számára gyenge megoldás lehet a korai szakaszban (Schütze et al., 2010).

Jelen kutatás célja a krónikus gerincfájdalommal élő személyek csoportjában releváns kognitív tényezők feltérképezése, és azok egészségi állapothoz kapcsolódó életminőségre gyakorolt hatásának vizsgálata. Olyan pszichológiai konstruktumokat vizsgálunk, mint a mindfulness, a fájdalom-katasztrofizáció és a félelemelkerülési hiedelmek. Azért is fontos ezen változók jelenlétének és egymásra gyakorolt hatásának vizsgálata, mert olyan körforgásba sodorhatják a beteget, ami maladaptív katasztrofizáló gondolatokat, mozgástól való félelmet, majd a mozgás tényleges kerülését, ennek következtében pedig szorongást, depressziót és dizabilitást eredményezhet (Vlaeyen et al., 1995), ráadásul a prognózist is ronthatja (Wertli, Rasmussen-Barr, Weiser, Bachmann \& Brunner, 2014). 


\section{MÓDSZERTAN}

\section{Minta}

Az adatfelvételre 2020 decembere és 2021 februárja között került sor. Az adatfelvétel online kérdőíves formában zajlott 70 fö bevonásával. A vizsgálati személyek gerincproblémával küzdő (gerincsérv, porckorongsérv, isiász, fibromialgia) emberek, akiket közösségi médiában található betegcsoport-oldalakon keresztül értünk el. Ezekben a csoportokban az adminisztrátor hozzájárulásával a kérdőívet részletes tájékoztatással együtt megosztottuk, melynek kitöltése körülbelül 25 percet vett igénybe. A résztvevők írásos tájékoztatást követően önkéntes alapon dönthettek a kutatásban való részvételről. A demográfiai adatokat lefedő kérdések után néhány, a betegségükre vonatkozó kérdést tettünk fel (diagnózis neve, gyógyszerszedési szokások), amelyek segítségével ki tudtuk szürni a három hónapnál régebb óta tartó gerincfájdalommal küzdő embereket. A kutatásból kizártuk azokat a személyeket, akiknek jelenleg nincsenek három hónapnál régebb óta tartó panaszaik (5fö), így végül 65 fő adataival számoltunk.

\section{Mérőeszközök}

A Mentális Figyelem és Tudatosság Kérdőív (Mindful Attention Awareness Scale - MAAS) mindennapi élményekkel kapcsolatos állításokat tartalmaz, ahol a kitöltóknek egy 1-től 6-ig terjedő Likert-skálán (1 - szinte mindig; 6 - szinte soha) kellett megjelölniük azt, hogy milyen gyakran tapasztalják az adott élményt. A kérdőív a mindfulnesst kognitív, érzelmi, fizikai és általános tartományokban méri. A 15 tétel a cselekvések tudatos reflexió nélküli végrehajtására kérdez rá, és minél magasabb pontszámot ér el a kitöltő a skálán (tehát minél kevésbé jellemző rá a tudatos reflexió nélküli cselekvés), annál magasabb jelentudatosság jellemzi. A kérdőív magyar nyelvű változatának pszichometriai adatai megfelelőek (Chronbach- $\alpha=0,78$; kéthónapos tesztreteszt reliabilitás: $0,71(\mathrm{n}=100 ; \mathrm{p}<0.001$; Simor, Petke \& Köteles, 2013). Jelen vizsgálatban az MAAS esetén a Cronbach- $\alpha$ megbízhatósági mutató értéke 0,909 volt.

A Fájdalom Katasztrofizálási Kérdőív (Pain Catastrophizing Scale - PCS) 13 állítást tartalmaz, amelyek összekapcsolódhatnak a fájdalom érzésével. A kérdőív három faktort tartalmaz: (1) rumináció, azaz fokozott fájdalommal kapcsolatos gondolatok (Chronbach- $\alpha=0,792$ ), (2) felnagyítás, azaz fájdalom és a fájdalmat okozó inger fenyegetésének eltúlzása (Chronbach- $\alpha=0,785$ ) és (3) tehetetlenség, a tehetetlen fájdalommal való megküzdés (Chronbach- $\alpha=0,883$ ). A résztvevőknek egy ötfokú Likert-skálán kellett értékelni, hogy mennyire jellemző rájuk az adott érzelem, amikor éppen fájdalmat élnek át ( 0 - egyáltalán nem jellemző; 4 - teljes mértékben, mindig jellemző). A PCS összpontszáma esetén a Cronbach- $\alpha$ megbízhatósági mutató értéke mintánkon 0,934. A kérdőív magyar változatának pszichometriai elemzése alapján a skála teszt-reteszt reliabilitása $r=0,70$; belső konzisztenciája pedig a teljes skála esetében Cronbach$\alpha=0,87$; az alskálákon pedig rumináció: 0,87; felerősítés: 0,66 ; és tehetetlenség: 0,78 (Kökönyei, 2008).

A Félelem és Elkerülési Hiedelmek Kérdőív (Fear and Avoidance Belief Questionnaire - FABQ-H) a fájdalommal kapcsolatos hiedelmeket és magatartásformákat vizsgálja. Egy 0-6-ig terjedő Likert-skálán kellett megválaszolni először öt kérdést, amely arra vonatkozik, hogy különböző fizikai aktivitások mennyire befolyásolják/befolyásolnák a kitöltők gerincfájdalmát ( 0 - egyáltalán nem értek egyet; 6 - teljes mértékben egyetértek). Ezután további 11 állításról kell eldönteni, hogy a kitöltők munkája vagy foglalkozása milyen hatással van/lehetne a fizikai fájdalmukra. Az aktivitás-alskála megbízhatósági mutató értéke 0,834, a munka-alskáláé 0,916 és az összpontszámé pedig 0,913 volt. A mérőeszköz magyar nyelvű verziójának pszichometriai mutatói jónak mondhatók, a kérdőív belső konzisztenciája 0,8 , a fizikai aktivitás alskálát nézve a Cronbach- $\alpha=0,66$, a munkával kapcsolatos félelem-alskála esetében Cronbach- $\alpha=0,86$ volt. (Simoncsics \& Strauder, 2017).

Az egészségi állapottal kapcsolatos életminőséget a Short Form Health Survey - SF-36 kérdőívvel mértük, ami 36 kérdés segítségével méri fel a kitöltő általános egészségi állapotáról alkotott véleményét. A mérőeszköz nyolc életminőségi dimenziót tartalmaz: fizikai aktivitás (Chronbach$\alpha=0,922)$, a fizikai problémákból adódó szerepkorlátozottság (Chronbach- $\alpha=0,867$ ), a testi fájdalom (Chronbach- $\alpha=0,894)$, az általános egészségérzet (Chronbach- $\alpha=0,720)$, a vitalitás 
(Chronbach- $\alpha=0,620)$, a társadalmi aktivitás (Chronbach- $\alpha=0,690)$, az érzelmi problémákból adódó szerepkorlátozottság (Chronbach$\alpha=0,840$ ) és az általános mentális egészség (Chronbach- $\alpha=0,836$ ). A skálán kapott 0-100-ig terjedő pontszám határozza meg a kitöltő életminőségének megfelelő értéket, ahol a 100-as érték jelenti a legjobb, a 0 pedig a legrosszabb életminőséget (Czimbalmos, Nagy, Varga és Husztik, 1999). Az SF-36 kérdőív egyes alskálái egy korábbi, közel 10000 főt magában foglaló kutatás során igen jó megbízhatósági mutatókkal rendelkeztek (fizikai aktivitás: 0,949; fizikai problémából adódó szerepkorlátozottság: 0,942; testi fájdalom: 0,970; általános egészségérzet: 0,877; vitalitás: 0,792; társadalmi aktivitás: 0,725; érzelmi problémából adódó szerepkorlátozottság: 0,939; általános mentális egészség: 0,814) (Füzesi, Illés, Tistyán \& Czirják, 2004).

\section{Statisztikai elemzések}

Az adatelemzés során az IBM SPSS Statistics 21 programot alkalmaztuk. Az adatok leíró elemzése mellett, a folytonos változók közötti kapcsolat elemzésére Pearson-féle korrelációelemzést végeztünk, míg a változók életminőségre gyakorolt hatását lineárisregresszió-elemzéssel (entermetódus) tártuk fel.

\section{EREDMÉNYEK}

\section{Minta}

Az elemzéshez tehát 65 kérdőív állt rendelkezésünkre, melyből 55 résztvevő nő $(84,6 \%)$ és 10 férfi (15,4\%). A válaszadók átlagéletkora 18-78ig terjedt, átlagéletkoruk pedig 49,2 év (SD: 11,7) volt.

A 65 főből 60 osztott meg információt a betegség pontos diagnózisáról, ahol a Bechterewkór avagy Spondylarthritis ankylopoetica (SPA) szerepelt a legtöbbször (30,9\%), ezt követték azok a betegek, akik esetében egynél több betegség áll fenn egyszerre $(23,6 \%)$, de a gerincsérv is említésre került $(12,7 \%)$, valamint a még folyamatban lévő diagnosztizálás (18,2\%).
Néhány esetben előfordult a reumatoid artritisz vagy más gyulladásos betegség $(5,5 \%)$, illetve egyéb betegségek (Scheurmann-kór, diszkopátia) (9,1\%). Kérdeztük a kitöltőket a fájdalomcsillapító-szedési szokásaikról is, ahol a kitöltők 30,8\%-a ritkábban, mint havonta, 15,4\%-a havonta egyszer-kétszer, 10,8\%-a havonta háromszor-négyszer, 16,9\%-a hetente többször, 7,7\%-a naponta, $18,5 \%$-a pedig naponta többször vesz be fájdalomcsillapító gyógyszert.

\section{A mindfulness, a fájdalom-katasztrofizáció, a félelemelkerülési hiedelmek és az életminőség kapcsolata}

Első lépésben megvizsgáltuk, hogy a vizsgálati csoportban az egyes pszichológiai, valamint egészségi állapotot mérő változók milyen kapcsolatban állnak egymással. A változók közötti együttjárásokat az 1. táblázat tartalmazza. Eredményeink szerint a mindfulness, a fájdalomkatasztrofizáció és a félelemelkerülési hiedelmek összpontszáma és alskálái között is közepes erősségű szignifikáns együttjárás figyelhető meg. A főbb eredményeket kiemelve, a mindfulness és a katasztrofizáció skálák között közepes erősségü negatív irányú kapcsolatot találtunk $(r=-0,512 ; p<0,01)$, míg a mindfulness és a félelemelkerülési hiedelmek között mérsékelt erősségű negatív irányút $(r=-0,424 ; p<0,01)$, a mindfulness és az életminőség között pedig közepes erősségű pozitív irányú lett a kapcsolat $(r=0,532 ; p<0,01)$.

\section{Az egészségi állapottal kapcsolatos életminőségre gyakorolt hatás}

A változók egészségi állapottal kapcsolatos életminőségre gyakorolt hatását többszörös lineáris regresszióval ellenőriztük. [2. táblázat] A főskálák összpontszámával számolva azt az eredményt kaptuk, hogy a modell a variancia $44,9 \%$ át magyarázza $\left(R^{2}=, 449 ; \quad F(3,64)=16,598\right.$; $p=0,000)$. A modellben a mindfulness $(\beta=0,270 ; p=0,020)$ a fájdalom katasztrofizáció $(\beta=-0,300 ; p=0,016)$ és a félelem és elkerülési hiedelmek $(\beta=-0,255 ; p=0,029)$ jól magyarázzák az egészségi állapottal kapcsolatos életminőség pontszámát. 
1. táblázat: A Pearson-féle korrelációs mátrix a pszichológiai változók és életminőség szerint

\begin{tabular}{|c|c|c|c|c|c|c|c|c|}
\hline Skála & 1. & 2. & 3. & 4. & 5. & 6. & 7. & 8. \\
\hline 1. MAAS Össz & - & - & - & - & - & - & - & - \\
\hline 2. Rumináció &,$- 513^{* *}$ & - & - & - & - & - & - & - \\
\hline 3. Felnagyítás &,$- 450 * *$ & - & - & - & - & - & - & - \\
\hline 4. Tehetetlenség &,- 470 ** & - & - & - & - & - & - & - \\
\hline 5. PCS Össz &,$- 512^{* *}$ & - & - & - & - & - & - & - \\
\hline 6. Fizikai aktivitás &,$- 292^{*}$ &, $343^{* *}$ &, $312 *$ & $347^{* *}$ &, $362^{* *}$ & - & - & - \\
\hline 7. Munka &,$- 412^{\star *}$ & $416^{* *}$ &, $453^{\star *}$ &, $524^{\star *}$ &, $511^{* *}$ & - & - & - \\
\hline 8. FABQ-H Össz &,$- 424^{\star \star}$ &, 446 ** & $463^{\star \star}$ &, $531^{\star \star}$ &, $526 * *$ & - & - & - \\
\hline 9. PF &, $364^{\star *}$ &,$- 246^{*}$ &,$- 370^{\star *}$ &,$- 410^{* *}$ &,$- 380 * *$ &,$- 334^{\star *}$ &,$- 547^{\star *}$ &,$- 544^{* *}$ \\
\hline 10. RP & NS & NS & NS &,$- 340^{* *}$ &,$- 279 *$ &,$- 271^{*}$ &,$- 480 * *$ &,$- 469 * *$ \\
\hline 11. BP & $285^{*}$ &,$- 261^{*}$ &,$- 387^{* *}$ &,$- 463^{* *}$ &,$- 416^{* *}$ & NS &,$- 514^{\star *}$ &,$- 460 * *$ \\
\hline 12. VT &, $501^{* *}$ &,$- 357^{\star *}$ &,$- 439 * *$ &,$- 369 * *$ &,$- 410^{*}$ & NS &,$- 304^{*}$ & NS \\
\hline 13. SF &, $459 * *$ &,$- 353^{\star *}$ &,$- 531^{* *}$ &,$- 514^{* *}$ &,$- 507^{* *}$ & NS &,$- 442^{* *}$ &,$- 397^{* *}$ \\
\hline 14. $R E$ &, $424^{* *}$ &,$- 371^{* *}$ &,$- 504^{\star *}$ &,$- 499 * *$ &,$- 498 * *$ & NS &,$- 426^{\star *}$ &,$- 406^{* *}$ \\
\hline 15. MH &, $601^{* *}$ &,$- 547^{\star *}$ &,$- 550 * *$ &,$- 509 * *$ &,$- 568 * *$ & NS &,$- 317^{*}$ &,$- 289 *$ \\
\hline 16. GH & ,296* & NS &,$- 375^{\star *}$ &,$- 343^{* *}$ &,$- 342^{* *}$ & NS &,$- 362^{* *}$ &,$- 351^{* *}$ \\
\hline 17. SF-36 Össz &, $532 * *$ &,$- 426^{\star *}$ &,$- 572^{* *}$ &,$- 578^{* *}$ &,$- 572^{* *}$ &,$- 251^{*}$ &,$- 567^{* *}$ &,$- 527^{* *}$ \\
\hline
\end{tabular}

Forrás: saját szerkesztés

$\mathrm{N}=65$. ${ }^{*} \mathrm{p}<0,05 ;{ }^{* *} \mathrm{p}<0,01$. NS-Nem szignifikáns.

Fizikai aktivitás (PF), Fizikai problémákból adódó szerepkorlátozottság (RP), Testi fájdalom (BP), Általános egészség (vitalitás) (VT), Szociális aktivitás (SF), Érzelmi problémákból adódó szerepkorlátozottság (RE), Általános mentális egészség $(\mathrm{MH})$, Általános egészségérzet $(\mathrm{GH})$

2. táblázat: A mért pszichológiai változók életminőségre gyakorolt hatása

\begin{tabular}{lccccc} 
& $\boldsymbol{B}$ & $\boldsymbol{S E} \boldsymbol{B}$ & $\boldsymbol{\beta}$ & $\boldsymbol{t}$ & $\boldsymbol{P}$ \\
\hline MAAS Össz & 2,203 &, 924 &, 270 & 2,384 &, 020 \\
\hline PCS Össz & $-3,020$ & 1,215 &,- 300 & $-2,486$ &, 016 \\
\hline FABQ Össz & $-1,402$ &, 628 &,- 255 & $-2,231$ &, 029 \\
\hline
\end{tabular}

Forrás: saját szerkesztés

Függő változó: SF Össz 


\section{MEGBESZÉLÉS}

Kutatásunkban tartós gerincfájdalommal élő személyek körében vizsgáltunk olyan pszichológiai tényezőket, mint a vonásszintű mindfulness, a fájdalom-katasztrofizáció és a félelemelkerülési hiedelmek, mindezt párhuzamba állítva az egészséghez kapcsolódó életminőséggel. A téma relevanciája abból fakad, hogy aláhúzza ezen pszichológiai tényezők a betegek egészségi állapotához kapcsolódó életminőségre gyakorolt hatását, aminek kapcsán egy olyan multidiszciplináris kezelés fontosságát hangsúlyozzuk, amelyben a fizikai tünetek mellett a pszichológiai tényezők is kiemelt szerepet kapnak a magasabb hatásfokú egészségkimenet elérése érdekében.

Eredményeink alapján, ahogy azt vártuk is, jelen, gerincfájdalommal élő személyeket vizsgáló kutatásunkban az összes változó főskálája szignifikáns kapcsolatban állt egymással. Az életminőség és a mindfulness az összes változóval negatív kapcsolatban állt, míg a fájdalomkatasztrofizáció és a félelemelkerülési hiedelmek között jellemzően pozitív volt az összefüggés. Érdemes lehet kiemelni, hogy pozitív az együttjárás a fájdalomból fakadó félelemelkerülési hiedelmek és a fájdalom-katasztrofizáció között, viszont a magasabb szintű mindfulness avagy jelentudatosság negatív irányú összefüggést mutat vele. A mindfulness és a katasztrofizáció két olyan változó lehet, amelyek tisztázhatják a fájdalomélményt és a fájdalomhoz való nehezített alkalmazkodást. Ahogy azt Schütze (2010) is javasolta, a mindfulness egyedülálló módon képes bejósolni a fájdalom-katasztrofizálást még a fájdalom időtartamától, a negatív affektusoktól és a fájdalomhoz kapcsolódó félelemtől függetlenül is. Mun, Okun \& Karoly (2014) ezzel megegyező eredményeket közölt, és csakúgy, mint mi, alátámasztották azt is, hogy a vonásszintű mindfulness szignifikáns negatív kapcsolatot mutat a fájdalom-katasztrofizációval. Ennek oka a szerzők szerint talán abban keresendő, hogy a mindfulness bizonyos aspektusai, konkrétan a jelen pillanatra való összpontosítás és a testi fájdalom felé irányuló ítélkezésmentes attitűd csökkentheti a katasztofizációt a folyamatos fájdalomingerekkel szemben. Mindemellett úgy tűnik, hogy ez a csillapító hatás látszólag független a fájdalom elfogadásától is. Ami a félelem és elkerülési hiedelmeket illeti, sokkal tágabb kontextusban érdemes értelmezni a vele járó mechanizmusokat. A fájdalom az egyik legerősebb averzív hajtóerő emberekben és állatokban egyaránt, és szoros kapcsolatban áll a félelemmel. Fordyce a fájdalomviselkedést az operáns kondicionáláshoz kapcsolta, a kezdeti hangsúlyt pedig a fájdalomviselkedés pozitív megerősítésére helyezte. Idővel azonban az „elkerülő tanulással" egészítette ki az elméletét, vagyis hogy a fájdalom miatti elkerülő magatartás negatív megerősítést eredményez (Fordyce et al., 1982 idézi Waddel, Newton, Henderson, Somerville \& Main, 1993). Krónikus fájdalommal élóknél ez az elméleti konstrukció a fájdalommal kapcsolatos félelemre alapoz, amely további fájdalmat, hipervigilanciát, fokozott félelmet és elkerülő magatartást, valamint félreértelmezett katasztrofális gondolatokat alakít ki a fájdalomról, ami intenzívebb fájdalmat és funkcionális károsodást eredményezhet (Lundberg et al., 2011).

A pszichológiai változókat együttesen vizsgálva tanulmányoztuk azok életminőségre gyakorolt hatását. Eredményeink alapján elmondható, hogy az alacsonyabb szintű egészségi állapothoz kapcsolódó életminőséget krónikus gerincfájdalommal élőknél - többek közt - a vonásszintű mindfulness, a fájdalom-katasztrofizáció és a félelemelkerülési hiedelmek jósolhatják be. A fájdalom a tartós gerincfájdalom esetében összetett, mivel nemcsak fizikailag zavaró, hanem hosszantartó jellege miatt pszichológiailag, társadalmilag és gazdaságilag is megterhelő lehet. A legtöbb krónikus fájdalomban szenvedő beteg különböző fizikai nehézségeket tapasztal meg, kezdve a járástól a mindennapos háztartás körüli feladatok elvégzéséig, sőt néhányuknak az olyan egyszerű tevékenységek, mint az ülés vagy az állás is nehézséget okoz. Ezen túlmenően a krónikus fájdalom befolyásolja a társas interakciókat is, mivel korlátozza a betegek aktivitását. Ezek a fájdalom okozta megpróbáltatások az alacsonyabb szintû életminőséghez járulhatnak hozzá (Bentsen, Hanestad, Rustøen \& Wahl, 2008).

A mindfulness hatása krónikus fájdalommal élőknél a meditáció potenciális előnyein keresztül érhető tetten, aminek során a beteg megtanulja a fájdalomingerét puszta testi érzésként megfigyelni a fájdalom érzelmi és kognitív komponenseinek leválasztásával. A hangsúlyt tehát arra fektetik, hogy az érzékelt szenzoros és affektív események pillanatnyiak és múlandóak, így 
további értékelést nem igényelnek. Ahogy arról Kabat-Zinn (1982) is beszámolt, egy ilyen alapokon nyugvó 8-hetes Mindfulness-alapú Stresszcsökkentő Tréning segítségével nemcsak a krónikus fájdalom tünetei javultak, hanem az életminőségben is pozitív változások következtek be. A meditáció során elsajátított mindfulness lehetővé teszi annak a belátását, hogy a fájdalommal kapcsolatos gondolatok nagyobb szenvedést okoznak, mint maga a fájdalom átélése, valamint a krónikus állapot elfogadása segít abban, hogy a társadalmi és kapcsolati szerepeikben meglássák az egyéb lehetőségeket. Hasonló módon az Elfogadás és Elköteleződés Terápia (Acceptance and Commitment Therapy; ACT, Wilson \& Sandoz, 2008) ugyancsak az érzetek, gondolatok és érzelmek objektív megfigyelésére alapoz, valamint az azoktól való tárgyilagos eltávolodásra, azok értékelés- és ítéletmentes elfogadására, és ezzel együtt a felettük gyakorolt merev kontrolltörekvések elengedésére. Ezen technikák elsajátítása oly módon javítja az életminőséget, hogy a gyakorlatok megtanítják a beteget arra, hogy nagyobb figyelmet fordítsanak a mindennapi életszükségleteire, valamint fokozzák az aktivitást, ami olyan pozitív érzelmek megtapasztalásához vezet, mint a béke, az öröm, az önbecsülés vagy az önbizalom. Azután, hogy a beteg megtanulja objektíven szemlélni a testi fájdalmát, és képes megfigyelni más testi érzéseket is, képes lehet ezeket a tudatos stratégiákat a mindennapjai során is alkalmazni. Ennek eredményeként megtanulja, hogyan tudja menedzselni az egészségét, és tudatosan elvégezni feladatait (Ardebil \& Banth, 2015).

Az életminőség kontextusában megannyi kutatás vizsgálta már a fájdalom-katasztrofizáció negatív hatását. Eredményeinkkel összhangban Semeru és Halim (2019) krónikus derékfájdalommal élők körében vizsgálódott, akik szintén úgy találták, hogy a katasztrofizáció jelentősen befolyásolja az életminőséget. Kiemelték emellett azt is, hogy az elfogadás pozitív hatásokkal bír, így az életminőség javítása érdekében csökkenteni kell a katasztrofizációt, és növelni az elfogadást. Mivel azok a betegek, akik hajlandóak elfogadni az állapotukat, olyan érzést tapasztalhatnak meg, ami hasonló a fájdalomcsillapító hatásához. Tanulmányukban az elfogadás azon tényezője, amely leginkább előidézheti ezt a fajta fájdalomcsökkenést, az az aktivitás volt. Ez azt jelenti, hogy azok a betegek, akik még mindig elvégzik a napi tevékenységeiket, általában jobb életminőségről számolnak be a fizikai megkönnyebbülés szempontjából. Ennek lehetséges magyarázata, hogy azok, akik aktívak maradnak, folyamatosan, de mégis akaratlanul edzik izmaikat, ami javítja az izomerőt és a mobilitást, ezáltal csökkenti a fájdalmat, csakúgy mint egy fizioterápia során (Arovah, 2010 idézi Semeru \& Halim, 2019). Krónikus derékfájdalommal élő kínai betegeket vizsgáló tanulmány során a szerzők megállapították, hogy a betegek globális életminősége rosszabb. Pontosabban az énhatékonyság, az aktív és passzív megküzdés, valamint a félelem és elkerülési hiedelmek mind fontos prediktor változói az életminőség fizikai komponensének, míg az énhatékonyság, a passzív megküzdés és a félelemelkerülési hiedelmek az életminőség mentális komponensét jósolták be (Du et al., 2018). Shim és munkatársai (2017) az általuk alkotott hipotetikus modellt tesztelve számoltak be ígéretes eredményekről. Reumatoid artritiszes betegek mintáját vizsgálva a kognitív, affektív és viselkedéses tényezők szerepét tanulmányozták az észlelt fizikai dizabilitás és az életminőség függvényében. Eredményeiket öszszefoglalva elmondható, hogy a fizikai aktivitással kapcsolatos félelemelkerülési hiedelmek, amelyeket feltehetően részben a fájdalomkatasztrofizáció félelmet előhívó kognitív folyamatai indukálnak, közvetlenül előre jelezték a nagyobb fizikai dizabilitást és depressziót, ami pedig negatív hatással volt a fizikai és pszichológiai életminőségre.

\section{KORLÁTOK ÉS KÖVETKEZTETÉSEK}

A kutatás eredményeinek elemzése során a vizsgálat bizonyos korlátai nem hagyhatók figyelmen kívül. Elsőként a résztvevők viszonylag kis elemszáma óvatosságra int az eredmények általánosíthatóságát illetően, ennek okán a vizsgált minta bővítése a jövőben mindenképpen szükséges lenne. Másodszor, a vizsgálatba való önkéntes jelentkezés felveti annak a lehetőségét, hogy azok körében volt nagyobb a részvételi hajlandóság, akiknél a fájdalom erősebben jelentkezik, ami a mintát és az eredményeket is torzíthatja. Részben ehhez is kapcsolódva indokoltnak látjuk a későbbi kutatások során a célcsoport diagnózisok mentén való célzott kiválasztását is, melyet akár az irányított beválogatás, akár nagyobb minta esetén a betegek homo- 
génebb csoportosítása lehetővé tenne. Jelen minta igen nagy részét női résztvevők képezték, mely miatt elképzelhető, hogy a gerincfájdalommal élő férfiak esetében nem ugyanezek az öszszefüggések igazolódnának. Végezetül a mindfulnesst a MAAS-nál megbízhatóbb ötfaktoros FFMQ (Baer et al., 2006) kérdőívvel lehetne mérni, továbbá igen értékes adatokat szolgáltathatna, ha a statisztikai próbákat kiegészíthetnénk folyamatmodellt tesztelő eljárással is, mely az esetleges mediáló tényezőkről is pontos képet festhetne.

A fenti korlátokat is figyelembe véve azonban, összegezve elmondható, hogy a tartós fájda- lommal élők egészségi állapotát megannyi pszichológiai tényező alakíthatja, kezdve a mindfulnesstől, a fájdalom-katasztrofizáción át a félelemelkerülési hiedelmekig. Az állapot romlásában valójában a pszichoszociális tényezők lehetnek dominánsak (Wertli et al., 2014), így a legcélszerübb az lenne, ha a betegek biopszichoszociális alapokon nyugvó multidiszciplináris kezelésben részesülnének. Ennek megfelelően a vizsgált változók olyan korai beavatkozási pontok lehetnek, amelyekre kellő figyelmet fordítva - kezdetben a kezelőorvos részéről, majd egyéb szakembereket bevonva bíztatóbb prognózis érhető el vagy várható.

Információk a szerzőkről:

Békefi Evelin; Pécsi Tudományegyetem Bölcsészet- és Társadalomtudományi Kar, Pszichológia Intézet, Személyiség- és Egészségpszichológia Tanszék, Pécs, bekefi.evelin@gmail.com

Teleki Szidalisz Ágnes, Pécsi Tudományegyetem Bölcsészet- és Társadalomtudományi Kar, Pszichológia Intézet, Személyiség- és Egészségpszichológia Tanszék, Pécs

\section{HIVATKOZÁSOK}

Apkarian, A. V., Baliki, M. N., \& Geha, P. Y. (2009). Towards a theory of chronic pain. Progress in neurobiology, 87(2), 81-97.

Ardebil, M. D., \& Banth, S. (2015). Effectiveness of mindfulness meditation on pain and quality of life of patients with chronic low back pain. International Journal of Yoga, 8(2), 128. https://doi.org/10.4103/0973-6131.158476

Baer, R. A., Smith, G. T., Hopkins, J., Krietemeyer, J., \& Toney, L. (2006). Five Facet Mindfulness Questionnaire. PsycTESTS Dataset. https://doi.org/10.1037/t05514-000

Bentsen, S. B., Hanestad, B. R., Rustøen, T., \& Wahl, A. K. (2008). Quality of life in chronic low back pain patients treated with instrumented fusion. Journal of clinical nursing, 17(15), 2061-2069. https://doi.org/10.1111/j.1365$\underline{2702.2008 .02232 . x}$

Bishop, S. R., Lau, M., Shapiro, S., Carlson, L., Anderson, N. D., Carmody, J., Segal, Z. V., Abbey, S., Speca, M., Velting, D., \& Devins, G. (2004). Mindfulness: A proposed operational definition. Clinical Psychology: Science and Practice, 11(3), 230-241. https://doi.org/10.1093/clipsy.bph077

Crombez, G., Eccleston, C., Van Damme, S., Vlaeyen, J. W., \& Karoly, P. (2012). Fear-avoidance model of chronic pain. The Clinical Journal of Pain, 28(6), 475-483. doi:10.1097/ajp.0b013e3182385392

Czimbalmos Á., Nagy Zs., Varga Z., \& Husztik P. (1999). Páciens megelégedettségi vizsgálat SF-36 kérdőívvel, a magyarországi normálértékek meghatározása. Népegészségügy, 1. szám, 4-19.

Du, S., Hu, L., Bai, Y., Dong, J., Jin, S., Zhang, H., \& Zhu, Y. (2018). The influence OF self-efficacy, Fear-Avoidance belief, and Coping styles on quality of life for Chinese patients with CHRONIC Nonspecific low back PAIN: A MULTISITE cross-sectional study. Pain Practice, 18(6), 736-747. doi:10.1111/papr.12660

Flor, H., \& Turk, D. C. (2011). Chronic pain: An integrated biobehavioral approach. Seattle: IASP Press.

Füzesi Zs., Illés T., Tistyán L., Czirják L. (2004). A felnőtt népesség egészségi állapota a Dél-dunántúli régióban. Pécs, Reproflex Kiadó és Nyomda Kft.

Gatchel, R. J., Peng, Y. B., Peters, M. L., Fuchs, P. N., \& Turk, D. C. (2007). The biopsychosocial approach to chronic pain: Scientific advances and future directions. Psychological Bulletin, 133, 581-624. 
Husky, M. M., Ferdous Farin, F., Compagnone, P., Fermanian, C., \& Kovess-Masfety, V. (2018). Chronic back pain and its association with quality of life in a large French population survey. Health and Quality of Life Outcomes, 16(1). doi:10.1186/s12955-018-1018-4

Kabat-Zinn, J. (1982). An outpatient program in behavioral medicine for chronic pain patients based on the practice of mindfulness meditation: Theoretical considerations and preliminary results. General Hospital Psychiatry, 4(1), 3347. https://doi.org/10.1016/0163-8343(82)90026-3

Kökönyei, Gy. (2008). Érzelemszabályozás krónikus fájdalomban. Doktori disszertáció. ELTE PPK Pszichológiatudomány Doktori Iskola, Budapest.

Központi Statisztikai Hivatal. (2020) Tehetünk az egészségünkért. https://www.ksh.hu/apps/shop.kiadvany?p_kiadvany id=1057181\&p temakor kod=KSH\&p lang=HU

Lundberg, M., Grimby-Ekman, A., Verbunt, J., \& Simmonds, M. J. (2011). Pain-related fear: a critical review of the related measures. Pain research and treatment, 2011, 494196. https://doi.org/10.1155/2011/494196

Merskey, H. (2002). Classification of chronic pain: Descriptions of chronic pain syndromes and definitions of pain terms. Seattle: IASP.

Mun, C. J., Okun, M. A., \& Karoly, P. (2014). Trait mindfulness and catastrophizing as mediators of the association between pain severity and pain-related impairment. Personality and Individual Differences, 66, 68-73. doi:10.1016/j.paid.2014.03.016

Quartana, P. J., Campbell, C. M., \& Edwards, R. R. (2009). Pain catastrophizing: A critical review. Expert Review of Neurotherapeutics, 9(5), 745-758. doi:10.1586/ern.09.34

Schütze, R., Rees, C., Preece, M., \& Schütze, M. (2010). Low mindfulness predicts pain catastrophizing in a fearavoidance model of chronic pain. Pain, 148(1), 120-127. https://doi.org/10.1016/j.pain.2009.10.030

Semeru, G. M., \& Halim, M. S. (2019). Acceptance versus catastrophizing in predicting quality of life in patients with chronic low back pain. The Korean journal of pain, 32(1), 22-29. https://doi.org/10.3344/kjp.2019.32.1.22

Shim, E.-J., Hahm, B.-J., Go, D. J., Lee, K.-M., Noh, H. L., Park, S.-H., \& Song, Y. W. (2017). Modeling quality of life in patients with rheumatic diseases: the role of pain catastrophizing, fear-avoidance beliefs, physical disability, and depression. Disability and Rehabilitation, 40(13), 1509-1516. doi:10.1080/09638288.2017.1300691

Simoncsics E., \& Stauder A. (2017). A félelem és elkerülési hiedelmek krónikus fájdalomban. A FABQ kérdőív magyar változatának fordítása és validálása. Orvosi Hetilap, 158(24), 949-955.

Simor, P., Petke, Z., \& Köteles, F. (2013). Measuring pre-reflexive consciousness: the Hungarian validation of the Mindful Attention Awareness Scale (MAAS). Learning \& Perception, 5(2), 17-29.

Sipe, W. E., \& Eisendrath, S. J. (2012). Mindfulness-based cognitive therapy: Theory and practice. The Canadian Journal of Psychiatry, 57(2), 63-69.

Sullivan, M. J., Thorn, B., Haythornthwaite, J. A., Keefe, F., Martin, M., Bradley, L. A., \& Lefebvre, J. C. (2001). Theoretical perspectives on the relation between catastrophizing and pain. The Clinical journal of pain, 17(1), 52-64. https://doi.org/10.1097/00002508-200103000-00008

Szántó S. (2012). A krónikus fájdalmak és gyógyításuk. Metabolizmus, 10(4), 265-267.

Treede, R. D., Rief, W., Barke, A., Aziz, Q., Bennett, M. I., Benoliel, R., Cohen, M., Evers, S., Finnerup, N. B., First, M. B., Giamberardino, M. A., Kaasa, S., Korwisi, B., Kosek, E., Lavand'homme, P., Nicholas, M., Perrot, S., Scholz, J., Schug, S., Smith, B. H., ... Wang, S. J. (2019). Chronic pain as a symptom or a disease: the IASP Classification of Chronic Pain for the International Classification of Diseases (ICD-11). Pain, 160(1), 19-27.

Turk, D. C., \& Flor, H. (1999). Chronic pain: A biobehavioral perspective. In R. J. Gatchel \& D. C. Turk (Eds.), Psychosocial factors in pain: Critical perspectives (p. 18-34). The Guilford Press.

Vlaeyen, J. W. S., Kole-Snijders, A. M. J., Boeren, R. G. B., \& van Eek, H. (1995). Fear of movement/(re)injury in chronic low back pain and its relation to behavioral performance. Pain, 62(3), 363-372. https://doi.org/10.1016/03043959(94)00279-n

Waddell, G., Newton, M., Henderson, I., Somerville, D., \& Main, C. J. (1993). A Fear-Avoidance Beliefs Questionnaire (FABQ) and the role of fear-avoidance beliefs in chronic low back pain and disability. Pain, 52(2), 157-168. https://doi.org/10.1016/0304-3959(93)90127-B

Wertli, M. M., Rasmussen-Barr, E., Weiser, S., Bachmann, L. M., \& Brunner, F. (2014). The role of fear avoidance beliefs as a prognostic factor for outcome in patients with nonspecific low back pain: a systematic review. The Spine Journal, 14(5), 816-836.e4. doi:10.1016/j.spinee.2013.09.036

Wilson, K. G., \& Sandoz, E. K. (2008). Mindfulness, values, and the therapeutic relationship in Acceptance and Commitment Therapy. Mindfulness and the therapeutic relationship, 89-106. 